\title{
The Diversity of Insect in Paddy Field in Karawang, West Java with Different Pest Management Techniques
}

\section{(Keanekaragaman Serangga pada Pertanaman Padi Lahan Persawahan di Karawang, Jawa Barat dengan Teknik Pengelolaan Hama yang Berbeda)}

\author{
Lutfi Afifah*, Darso Sugiono \\ (Diterima Juni 2019/Disetujui Maret 2020)
}

\begin{abstract}
The practice of rice crop cultivation will affect the trophic structure and the diversity of insects that are formed. One of the common cultivation practices carried out by farmers was the control of pests by using pesticides. This study aimed to find out which pest management strategies that are effective in maintaining environmental health and understanding how natural enemies were affected by the application of synthetic pesticides. The first treatment was paddy field with integrated pest management (IPM), the second treatment was conventional rice field with a technique of chemical pest management (C-T), while the third treatment was mixed pest management (M-T). Insect sampling was conducted using sweep net, pitfall trap, and direct observation for $\mathbf{1 0}$ weeks after planting. Overall, it was found 100 morphospecies, 9 Orders, 56 families, with a total abundance of 6242 individuals per planting season. Based on functional roles it was found $39 \%$ as herbivores, $30 \%$ as predators, and $14 \%$ as parasitoids, $1 \%$ pollinators, and $13 \%$ decomposers. High insect diversity and abundance were found in the plots using low synthetic pesticides. The C-T control plot had a lower relative abundance of herbivorous insects, parasitoid insects, predators, and decomposers than the other control plots. $\mathrm{H}^{\prime}$ and D index in the Integrated Pest Management (IPM) and Mixed Pest Management (M-T) plots did not show significant differences but differed significantly from the Chemical Control plot (C-T). Therefore, controlling the herbivore insects could apply the pest management based on IPM strategies.
\end{abstract}

Keywords: Diversity of insects, integrated pest management (IPM), natural enemies, pesticides, rice pests

\section{ABSTRAK}

Praktik budi daya tanaman padi akan memengaruhi struktur trofik dan keanekaragaman serangga yang terbentuk. Salah satu praktik budi daya yang umum dilakukan oleh petani adalah pengendalian hama dengan menggunakan pestisida. Penelitian ini bertujuan untuk mengetahui strategi pengelolaan hama mana yang efektif dalam menjaga kesehatan lingkungan dan memahami bagaimana musuh alami terpegaruh oleh aplikasi pestisida sintetis. Perlakuan pertama adalah sawah dengan pengelolaan hama terpadu (IPM), perlakuan kedua adalah sawah konvensional dengan teknik pengelolaan hama kimia (C-T), sedangkan perlakuan ketiga adalah pengelolaan hama campuran (M-T). Pengambilan sampel serangga dilakukan dengan menggunakan jaring serangga, perangkap lubang jebakan, dan pengamatan langsung selama 10 minggu setelah tanam. Secara keseluruhan ditemukan 100 morphospecies, 9 Ordo, 56 famili, dengan jumlah total 6242 individu per musim tanam. Berdasarkan peran fungsional didapatkan 39\% sebagai herbivora, $30 \%$ sebagai predator, $14 \%$ sebagai parasitoid, $1 \%$ penyerbuk, dan $13 \%$ pengurai. Pengelolaan hama, terutama dalam penggunaan pestisida sintetis, akan memengaruhi kekayaan spesies dan kelimpahan serangga yang terkandung di dalamnya. Keanekaragaman serangga dan kelimpahan yang tinggi ditemukan pada penggunaan pestisida sintetis yang rendah. Plot kontrol C-T memiliki kelimpahan relatif yang lebih rendah pada serangga herbivora, serangga parasitoid, predator, dan pengurai dibandingkan dengan plot kontrol lainnya. Indeks $H^{\prime}$ dan $D$ pada plot Pengelolaan Hama Terpadu (PHT) dan Pengelolaan Hama Campuran (MT) tidak menunjukkan perbedaan yang signifikan, tetapi berbeda secara signifikan dibandingkan dengan plot Pengendalian Kimia (CT). Oleh karena itu, untuk mengendalikan serangga herbivora, pengelolaan hama yang didasarkan pada strategi PHT dapat digunakan.

Kata kunci: hama padi, keanekaragaman serangga, musuh alami, pengendalian hama terpadu (PHT), pestisida

\section{INTRODUCTION}

Insects have an important role in various types of ecosystems (Speight et al., 2008). Insects are one of

Department of Agrotechnology, Faculty of Agriculture, Universitas Singaperbangsa Karawang, Jl. HS Ronggo Waluyo, Teluk Jambe Timur, Karawang 41361

* Correspondence Writer:Email: lutfiafifah@staff.unsika.ac.id the constituents of trophic levels that are important in the ecosystems of rice crop, especially their roles as pests that cause damage and loss of rice yields. This problem received a special attention from the farmers, especially in the practice of rice cultivation. The practice of crop cultivation and the state of landscape around the rice plantations will affect the trophic structure and the formed food web (Rizali et. al., 2002). One of common cultivation practices carried out by the 
farmers is pest control using pesticides. The food network approach can be used to evaluate the impacts of applications of pest-control techniques. This recommendation is based on the reality that pest control activities will affect the food web in an ecosystem.

In many cases, the use of pesticides intended to reduce the impact of loss production will result in undesirable environmental changes (Altieri \& Nicholls 2004). Pesticides can directly or indirectly affect ecology, in this case pest insects as the main target and the other insects in the ecosystem will be also affected (Zacharia 2011). Various studies showed that the intensity of using synthetic pesticides in rice production were very high. The synthetic pesticide uses in Karawang were about 11 times per planting season (Wiyono et al. 2014).

The efforts to increase rice production have been carried out in various ways, one of which is to apply techniques to control rice pests both chemically by using synthetic pesticides, as well as by biological control by utilizing natural enemies and botanical pesticides (Marwoto et al. 1991). According to Marwoto et al. (1991) natural enemies of soybean pests have been able to suppress soybean population at a stable level. Pest control efforts must pay attention to the survival of natural enemies in the crop.

The pest-management techniques used were by comparing the diversity on integrated pest management (IPM), conventional rice fields with chemical pest-management techniques (C-T), and mixed pest-management techniques (M-T). Research on a community structure, especially regarding to the diversity of insect in rice plant, was very important to do because the complexity of interaction process in the tropic level that occur in nature can help to develop the better strategies for managing insect pests. The purposes of this study were to find out which pest management strategies are effective in maintaining environmental health and understanding of how the natural enemies are affected by the application of synthetic pesticides.

\section{MATERIALS AND METHODS}

\section{Land Preparation}

The size of each trial plot was $4 \times 5 \mathrm{~m}\left(20 \mathrm{~m}^{2}\right)$ and each treatment was repeated five times. The nursery was fertilized with urea with $20-40 \mathrm{~g}$ urea $/ \mathrm{m}^{2}$. The nursery area was given compost mixed with wood husk or ash at 2-4 kg/m². Planting of young seedlings was conducted at the age of 10-17 days after spreading. The spacing was adjusted to the variety and fertility of the soil $(25 \times 25 \mathrm{~cm})$ with the number of seeds per planting hole between 2-3 seeds. Fertilization was conducted twice, at 14 and 35 days after planting. Fertilizers used were urea as much as $200 \mathrm{~kg} / \mathrm{ha}$, SP36 at a level of $100 \mathrm{~kg} / \mathrm{ha}$, and NPK Phonska at the level of $100 \mathrm{~kg} / \mathrm{ha}$. The experiment layout was conducted using a Complete Randomized Block Design.

\section{Pest-Management Techniques}

The rice pest-management techniques used in this study included: integrated pest management (IPM), chemical pest-management techniques (C-T), and mixed pest-management techniques (M-T) (Table 1). In each plot, the pest-management techniques were carried out by the same tillage, standard fertilization, weeding, and the same irrigation. Each treatment plot was repeated five times.

\section{Sampling Method}

Observations of pest and natural enemies were carried out during one planting season, since the plants were in the stages of 2 to 10 weeks after planting, with intervals every two weeks/at even week. Observations of pest and natural enemies were carried out by using two methods, namely direct observation and indirect observation. Indirect observation of the diversity of insect species in rice plantations was carried out by using a sweep net and a pitfall trap.

\section{Insects Identification}

Identification was conducted by referring to the identification book (McAlpine 1987; Goulet \& Huber 1993; CSIRO 1996; Schuh \& Slater 1996; Taichi \& Mohamed 2004). Furthermore, the insects were grouped into groups of herbivores, predators, parasitoids, decomposers, or other insects.

\section{Data Processing}

The observation data were entered into the pivot table in Microsoft Excel 2016 software, then used as a database for creating tables and graphs for the analysis process. Analysis of variance (ANOVA) was carried out on data on diversity and abundance of insect species using the one-way ANOVA method using SAS software version 9.1 .3 at the $5 \%$ real level.

Table 1 Components of pest management techniques used

\begin{tabular}{|c|c|c|c|}
\hline Treatment & $\begin{array}{c}\text { Integrated Pest } \\
\text { Management (IPM) }\end{array}$ & $\begin{array}{l}\text { Chemical Control Treatment } \\
(\mathrm{C}-\mathrm{T})\end{array}$ & $\begin{array}{l}\text { Mixed Pest Management } \\
\text { Technique (M-T) }\end{array}$ \\
\hline Seed treatment & PGPR $50 \mathrm{~g}+5 \mathrm{~L}$ water & Soaking with salt solution & $\begin{array}{l}\text { Soaking with Paenibacillus } \\
\text { polymyxa }\end{array}$ \\
\hline Synthetic pesticides & Monitoring & $\begin{array}{l}\text { Chemical pesticides ( } 5 \\
\text { times/planting season) }\end{array}$ & Once on 4 weeks after planting \\
\hline $\begin{array}{l}\text { Biological agents } \\
\text { and botanical } \\
\text { pesticides }\end{array}$ & $\begin{array}{l}\text { Paenibacillus polymyxa, } \\
\text { Beauveria bassiana, } \\
\text { Neem }\end{array}$ & 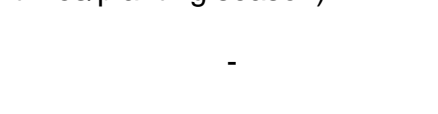 & $\begin{array}{l}\text { Neem and Paenibacillus } \\
\text { polymyxa }\end{array}$ \\
\hline
\end{tabular}




\section{RESULT AND DISCUSSION}

\section{Insect Diversity at Different Management Systems}

Based on the results of species-accumulation calculations, it appeared that all species-accumulation curves had not reached asymptote sampling. The data showed that the number of arthropod species found in each treatment plot was not optimal. The number of species collected compared with the Jacknife-1 estimator in IPM plot was $69 \%$, in C-T plot was $73 \%$, and in $\mathrm{M}-\mathrm{T}$ plot was $75 \%$ (Figure 1). The richness of insect species compared with the estimators was generally between $70-80 \%$.

Overall, there were 100 morphospecies consisted of 9 Orders, 56 Families, with a total abundance of 6242 individuals per planting season. Based on the research conducted by Settle et al. (1996), it was explained that paddy fields had an abundant species richness and rich in organic material. Some of the factors that influence species diversity were the previous planting cycle, organic materials from irrigation water, and also algal growth. In the wetland rice ecosystem, Rizali et al. (2002) obtained 435 species meanwhile Settle et al. (1996) obtained 765 species. There are several factors affecting the differences in abundance and types of insects found. Altieri \& Nicholls (2004) state that biodiversity in agroecosystems depends on four characteristics including the diversity of vegetations around the agroecosystems, the diversity of cultivated crops in agroecosystems, the intensity of land management, and the isolation of agroecosystem from natural vegetation. Ovawanda (2016) states that the ecosystem of organic rice will increase the richness of species, the evenness of species, as well as the heterogeneity of insects.

The abundances of arthropod species found were 9 Orders consisted of $13 \%$ in the Order of Coleoptera, $2.7 \%$ in the Order of Diptera, $67.5 \%$ in the Order of Hemiptera, $2.6 \%$ in the Order of Hymenoptera, $9.5 \%$ in the Order of Lepidoptera, $0 \%$ in the Order of Mantodea, $1.5 \%$ in the Order of Odonata, $0.6 \%$ in the Order of Orthoptera, and $2.6 \%$ in the Order of Thysanoptera
(Table 2). The highest abundance of the species was found in the order of Hemiptera $(67.5 \%)$. In this experiment, It was also found aphids, a new pest in rice plantations (Harleni et al. 2015). However, based on the highest abundance of morphospecies during the growing season, the order found was Leptocorisa oratorius stinks, brown planthopper Nilaparvata lugens, green leafhopper Nephotettix virescens, leaf planthopper Anoscopus sp., and predator beetle Paederus fuscipes.

Based on species richness, it was found that the orders Diptera, Coleoptera, and Hymenoptera showed the higher number of species than the other orders. The species richness of each order were: 25 species in Diptera, 19 species in Coleoptera, 18 species in Hymenoptera, 15 species in Hemiptera, 9 species in Orthoptera, 6 species in Odonata, 4 species in Lepidoptera, 3 species in Thysanoptera, and 1 species in Mantodea (Figure 2).

The high species found in the Diptera order are thought to be due to the ecosystem factors of paddy rice as an aqueous-soil ecosystem. Daly et al. (1978) suggested that the dominating aquatic insect was the Diptera larvae. The age factor of rice plants, the weather conditions at the time of taking samples, and the state of habitat around the land will greatly affect the abundance and richness of insect species. The high richness of morphospecies from the Diptera order

Table 2 Diversity of Arthropoda Species found in rice plantations in Pangkalan, Karawang during the growing season

\begin{tabular}{lcc}
\hline \multicolumn{1}{c}{ Order } & $\begin{array}{c}\text { Abundance of } \\
\text { Species }\end{array}$ & Percentage (\%) \\
\hline Coleoptera & 814 & 13.0 \\
Diptera & 167 & 2.7 \\
Hemiptera & 4213 & 67.5 \\
Hymenoptera & 165 & 2.6 \\
Lepidoptera & 590 & 9.5 \\
Mantodea & 1 & 0.0 \\
Odonata & 94 & 1.5 \\
Orthoptera & 36 & 0.6 \\
Thysanoptera & 162 & 2.6 \\
\hline
\end{tabular}

Species accumulative curves

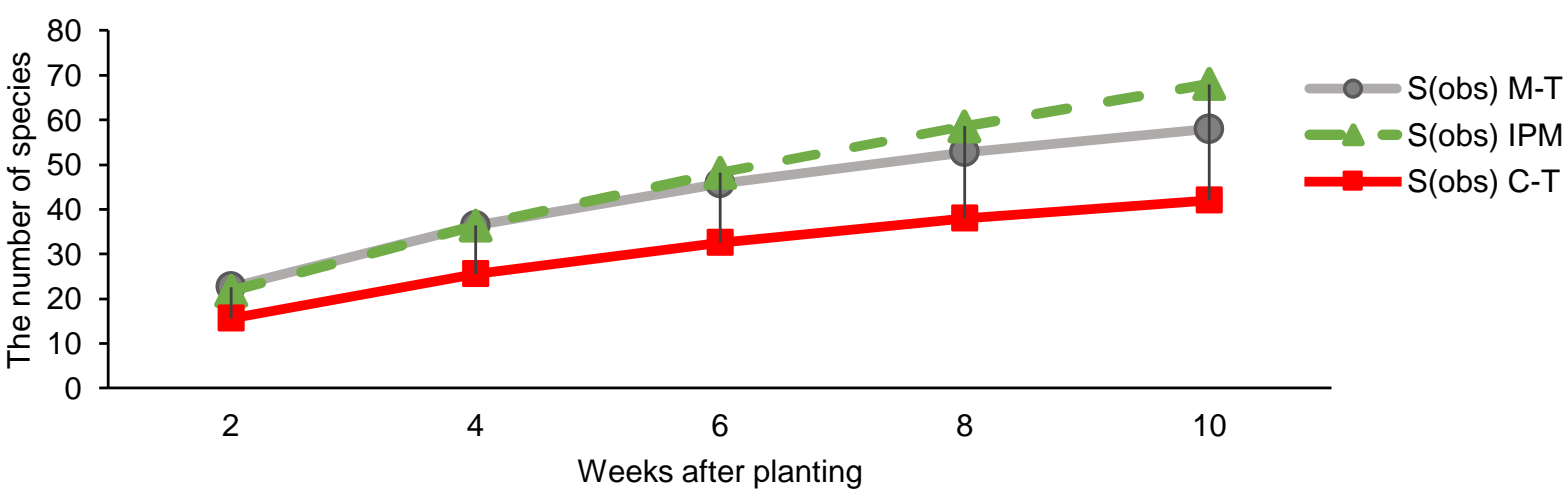

Figure 1 Species-accumulation curves during observations 1-10 weeks after planting on each plot of pest management. IPM = Integrated Pest Management; C-T = Chemical Control Treatment; and M-T = Mixed Pest Management Technique. 


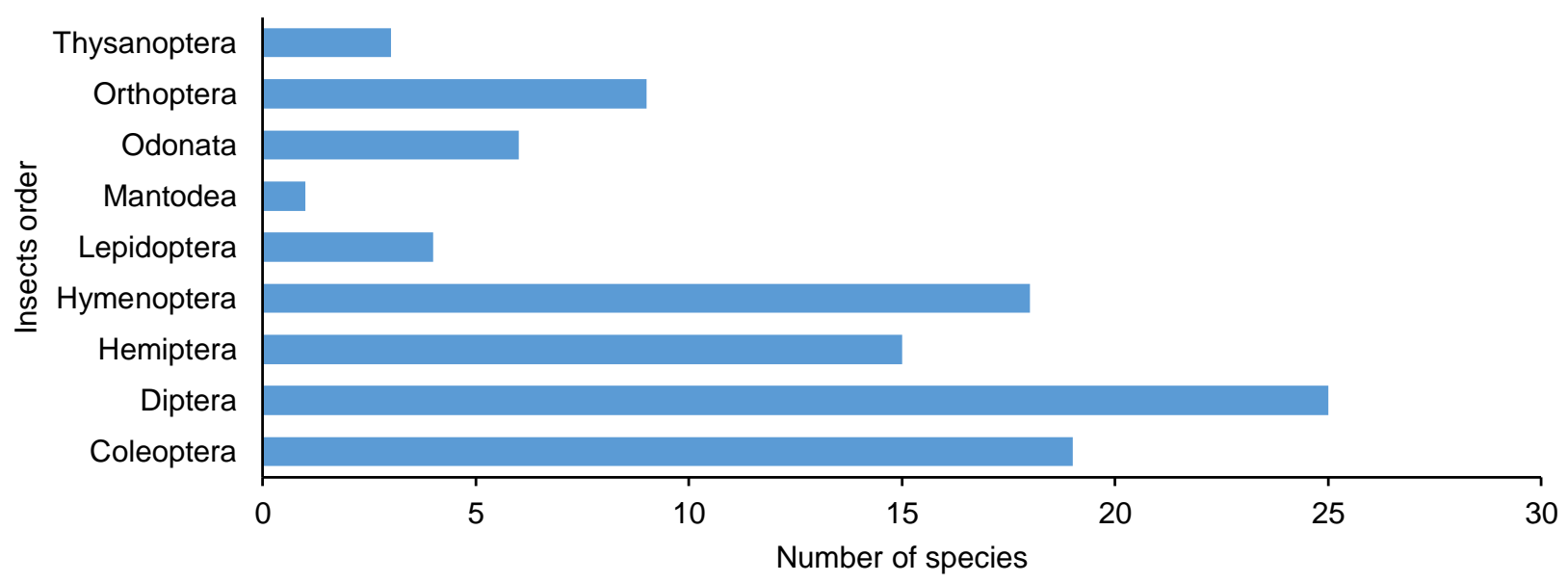

Figure 2 Richness of each insect order found in all treatments in rice plantations.

was reported by Rizali et al. (2002) on forest edge rice fields which reached $37.9 \%$.

In general, it showed that the plot of IPM treatment showed a higher species richness of 2.79 (Table 3). The $\mathrm{H}^{\prime}$ index close to 3.00 shows a high species richness. The lowest $\mathrm{H}^{\prime}$ index was found in the C-T treatment plot. This lowest $\mathrm{H}^{\prime}$ index was assumed to be caused by the application of synthetic pesticides causing a low species richness (Table 3). Hillebrand et al. (2008) proved that the relative abundance of species and species richness had almost in the same range due to the differences in the ecosystem health.

The biodiversity that exists in agricultural ecosystems such as rice fields can affect plant growth and production, through their effects on the nutrient rotation system, changes in microclimate, and detoxification of chemical compounds (Altieri \& Nicholls 2004). When compared between agricultural ecosystems and forest ecosystem, the diversity is higher in forest ecosystems (Janzen 1987). Evenness index in agricultural ecosystems is also lower than in forest ecosystems. Habitat factors are thought to be factors influencing this difference since unspoiled habitats have high insect diversity. In addition, on agricultural land, the existence of agricultural practices has a strong influence on the diversity of insect (Downie et al. 1999).

\section{Fluctuations in the Population of Insect Based on Different Pest Managements}

Fluctuations of population in herbivorous insects were generally showing the same trend between different pest managements, but at the end of the planting period of 10 weeks after planting there was a significant increase in herbivorous insects especially in the C-T plot (Figure 3a). The increase in the population of herbivorous insects was dominated by Leptocorisa oratorius. It is suspected that harvesting one week earlier in the rice crop around the research plot caused the migration of $L$. oratorius to the research plot. This result was different from the results reported by
Table 3 The diversity index of insects in different pest management systems in Pangkalan, Karawang, West Java

\begin{tabular}{rrrr}
\hline & \multicolumn{3}{c}{ Pest Management System } \\
\cline { 2 - 4 } & \multicolumn{1}{c}{ M-T } & \multicolumn{1}{c}{ PHT } & \multicolumn{1}{c}{ C-T } \\
\hline O & 10.00 & 11.00 & 10.00 \\
F & 35.00 & 41.00 & 30.00 \\
S & 59.00 & 69.00 & 43.00 \\
N & 1713.00 & 2375.00 & 1971.00 \\
H' & $2.68 \mathrm{a}$ & $2.79 \mathrm{a}$ & $2.06 \mathrm{~b}$ \\
D & $0.87 \mathrm{a}$ & $0.90^{\mathrm{a}}$ & $0.72 \mathrm{~b}$ \\
E & $0.65^{\mathrm{a}}$ & $0.65^{\mathrm{a}}$ & $0.54 \mathrm{~b}$ \\
\hline
\end{tabular}

Description: Number of orders (O); family $(\mathrm{F})$; species $(\mathrm{S})$; individual insects $(\mathrm{N})$; Shannon Diversity Index $\left(\mathrm{H}^{\prime}\right)$; Shannon Abundance Index (D); and distribution (E) in different pest managements. IPM = Integrated Pest Management; C-T: = Chemical Control Treatment; and M-T = Mixed Pest Management Technique.

Herlinda et al. (2019) that the most dominant phytophagous insects found in the rice field were brown planthopper (BPH) Nilaparvata lugens, Nephotettix cincticeps, and Epichlorops sp. The results showed that the abundance of the phytophagous insects in the rice at $28,42,56$, and 84 days after planting had no significant difference among treatments on different planting methods and varieties, However, the difference in the abundance was occurred at 70 days after planting.

At the beginning of the planting period, the parasitoid population in IPM plot showed a higher abundance than at 6 weeks after planting when the population dropped dramatically. The parasitoid population on the IPM plot then raised again from 8-10 weeks after planting. At 6 weeks after planting, synthetic insecticides were sprayed, and action were thought to cause a low abundance of parasitoid populations during the week. The high parasitoid abundance was observed in the M-T plot (Figure 3b). The abundance of predators and saprophages in the IPM plot showed a high abundance at the beginning of planting, and the peak was at 6 weeks after planting, 
then the population decreased at 8 weeks after planting and raised again at 10 weeks after planting (Figure 3 $c-d)$.

The management of plant health will have an impact on the abundance of insects contained therein. C-T plots had a relative abundance of herbivorous insects, parasitoid insects, predators, and decomposers that were lower than the other control plots (Figure 3). In CT plot, spraying synthetic pesticides was carried out six times during one planting season. This result is in line with the result reported by Ristyadi (2011) which states that the use of synthetic pesticides has an abundance of arthropods which are low compared to the treatments with biopesticides and without pesticides. In the other research, the abundances of predators, parasitoid, and herbivore in plots sprayed with bioinsecticide were higher and significantly different from the abundance in plots sprayed with abamectin. Controlling the herbivore insects could use bioinsecticides derived from entomopathogenic fungi (Prabawati et. al. 2019). During a planting season on rice according to Karenina et al. (2019) were found 25 herbivore species, 34 spider species, and 24 species of predatory insects. The lowest herbivore population and spider abundance were found on the plot spayed with synthetic insecticide and they were significantly a. Herbivore

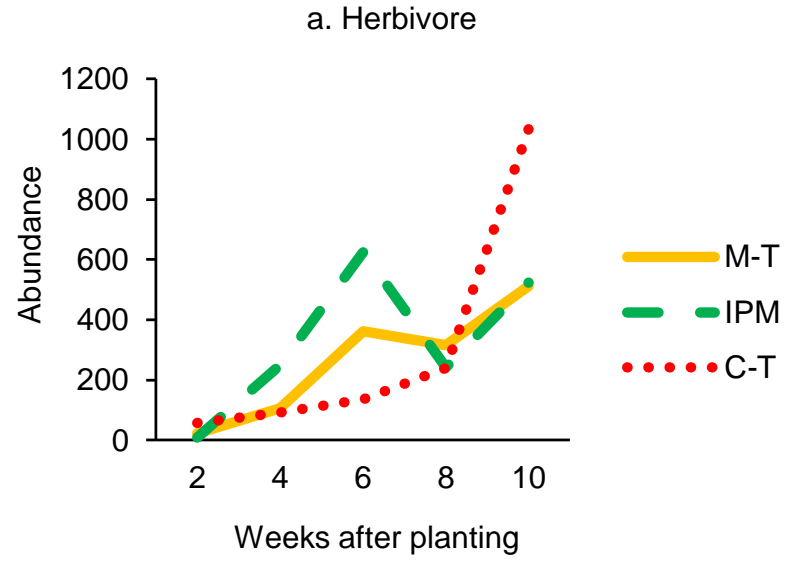

c. Predator

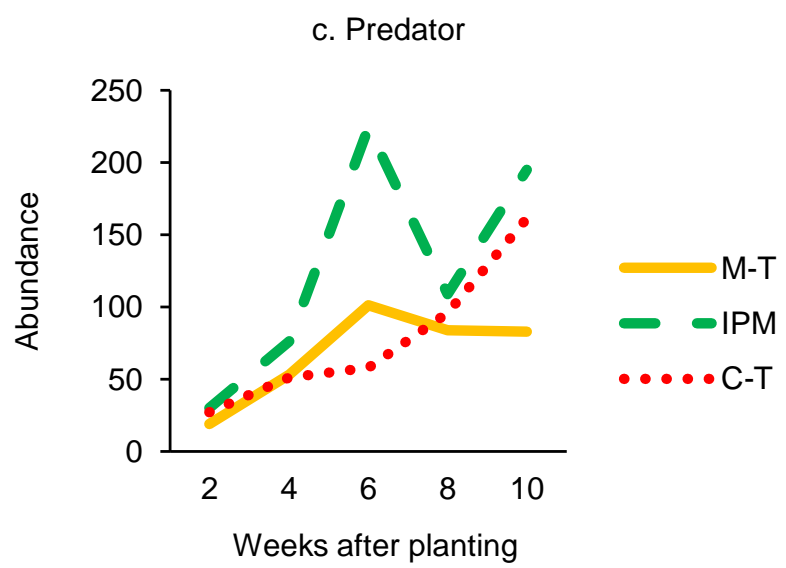

different from the other refugia-rice plots. The most abundant spiders and predatory insects were found in rice surrounded by refugia and were not significantly different from those of rice surrounded by vegetables.

\section{Composition and Functional Role of Insects in Rice Plants}

The description of richness of the insect species in the three types of pest management has an overlapping number of species (Figure 4). A similar thing was found in the study of Afifah et al. (2015) which explained that the description of the richness of insect species by the differences of plant health management in soybean plants had an overlapping number of species. The number of overlapping morphospecies occupied all three pest-control technologies were 31 species. Species that can only be found in IPM plots were 22 species, in M-T plot were 14 species, and in $\mathrm{C}$-T plot were 5 species. These species were unique because they were only found in these plots and were not found in the other plots. In addition, IPM plot showed that they were richer in insect species. The species compositions among different plant health managements cannot be separated because it had the same resources (paddy plant). This can be seen from the results of the diagram of the species collection

\section{b. Parasitoid}

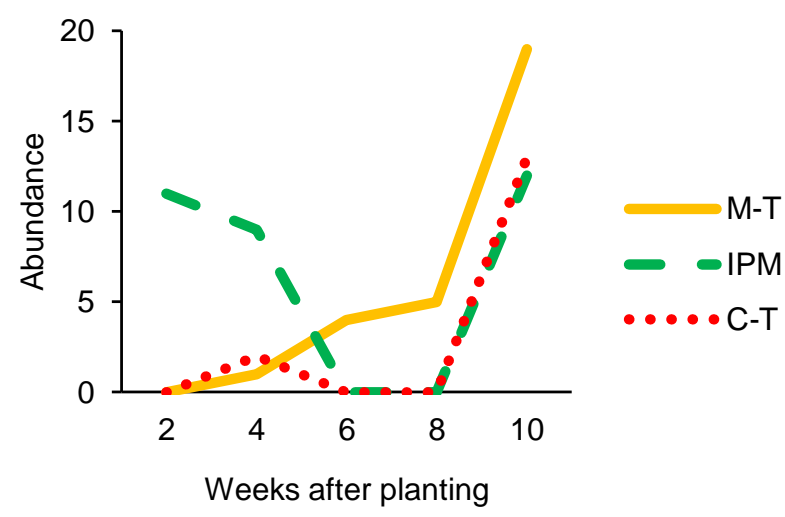

d. Saprophage

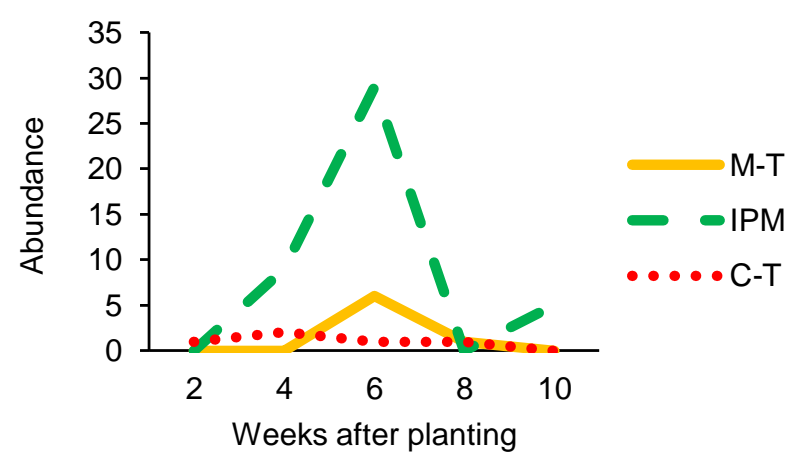

Figure 3 Profile of population dynamics of herbivorous insects. a) Parasitoid; b) Predators; c) Saprophages; and d) In the treatment of different pest management. IPM = Integrated Pest Management; C-T = Chemical Control Treatment; and $\mathrm{M}-\mathrm{T}=$ Mixed Pest Management Technique. 
which shows the overlapping of species that occupy the three pest-control technologies.

In this study, it was known that insects associated with rice were recorded 101 morphospecies, 39\% as herbivores, $30 \%$ as predators, $14 \%$ as a parasitoid, $1 \%$ as a pollinator, and $13 \%$ as decomposers (Figure 5). These results were different from the results reported by Herlinda et al. (2019) that found 35 kinds of herbivores $(30 \%), 59$ predators $(51 \%), 8$ parasitoids $(7 \%)$, and 14 detritivores (12\%). The results reported by Settle et. al. (1988) on lowland irrigated rice in Indonesia showed that a majority of guilds were Predator with 306 species (40\%), Parasitoid with 187 species $(24.4 \%)$, Detritivore and plankton feeders with 145 species (18.95\%), and Herbivore with 127 species $(16.6 \%)$. The highest abundances of herbivorous insects were brown planthopper Nilaparvata lugens (Hemiptera: Delphacidae) (Figure 6a), green leafhopper Nephotettix virescens (Hemiptera: Cicadellidae) (Figure 6b), and Leptocorisa oratorius

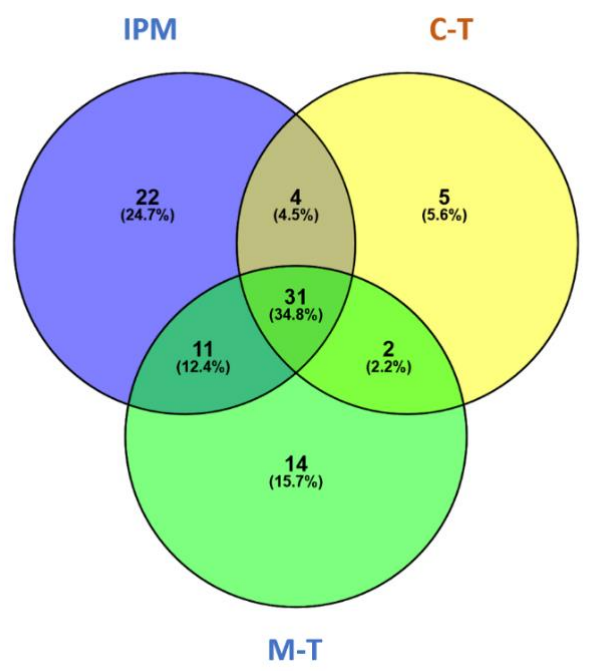

Figure 4 Species set of different types of different pest control technologies. IPM = Integrated Pest Management; C-T = Chemical Control Treatment; and $\mathrm{M}-\mathrm{T}=$ Mixed Pest Management Technique.

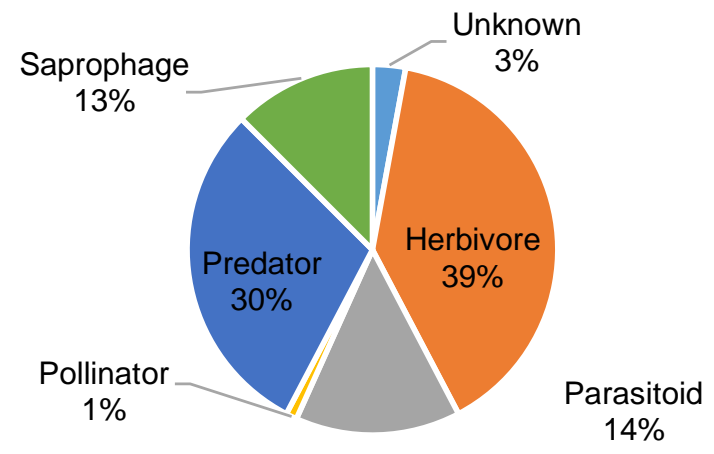

Figure 5 Percentages of richness of arthropod species found based on their functional roles.
(Hemiptera: Alydidae) (Figure 6c). The highest abundance of predatory insects was Paederus fuscipes (Dermaptera: Staphylinidae) (Figure 6d). The most common parasitoids were Phoridae sp.1 (Figure $6 e$ ) and saprofag were mostly from Sarcophagidae sp.1 (Figure 6f). The data found in this study were similar to the results reported by Afifah et al. (2015) that the percentages of herbivores were higher than the other ecological roles. This result is because herbivores are at the lowest level below producers, namely plants.

\section{CONCLUSION}

Finally, the results of this study indicate that different pest management systems, especially in the case of the use of synthetic pesticides will have an impact on the abundance and richness of insects species. High diversity and abundance of insects were shown in the use of low synthetic pesticides. C-T (Chemical Control Treatment) plots have a relative abundance of herbivorous insects, parasitoid, predators, and decomposers that lower than the other plots. In general, it showed that the $H^{\prime}$ and $D$ index in the plot of IPM (Integrated Pest Management) and M-T (Mixed Pest Management Technique) did not show a significant difference but showed significantly different effects compared to Chemical Control plot (C-T).

\section{ACKNOLEDGEMENT}

The author would like to thank Kemenristek Dikti for the assistance of the "Penelitian Dosen Pemula", Ristekdikti Research grant in 2017. Decree: 42/E /KPT/2017; Contract Agreement: 091/SP2H/UN64.10/ $\mathrm{LT} / 017$.

\section{REFERENCES}

Afifah L, Hidayat P, Buchori D, Rahardjo BT. 2015. Pengaruh Perbedaan Pengelolaan Agroekosistem Tanaman Terhadap Struktur Komunitas Serangga Pada Pertanaman Kedelai Di Ngale, Kabupaten Ngawi, Jawa Timur. Jurnal Hama dan Penyakit Tumbuhan Tropika. 15(1): 53-64. https:// doi.org/10.23960/j.hptt.11553-64

Altieri M, Nicholls C. 2004. Biodiversity and pest management in agroecosystems. New York (US): Food Product Press. https://doi.org/10.1201/ 9781482277937

[CSIRO] Commonwealth Scientific and Industrial Research Organization. 1996. The Insect of Australia: A Teexbook for Students and Research Workers. Second edition. Melbourne University Press. Victoria. $1029 \mathrm{p}$. 


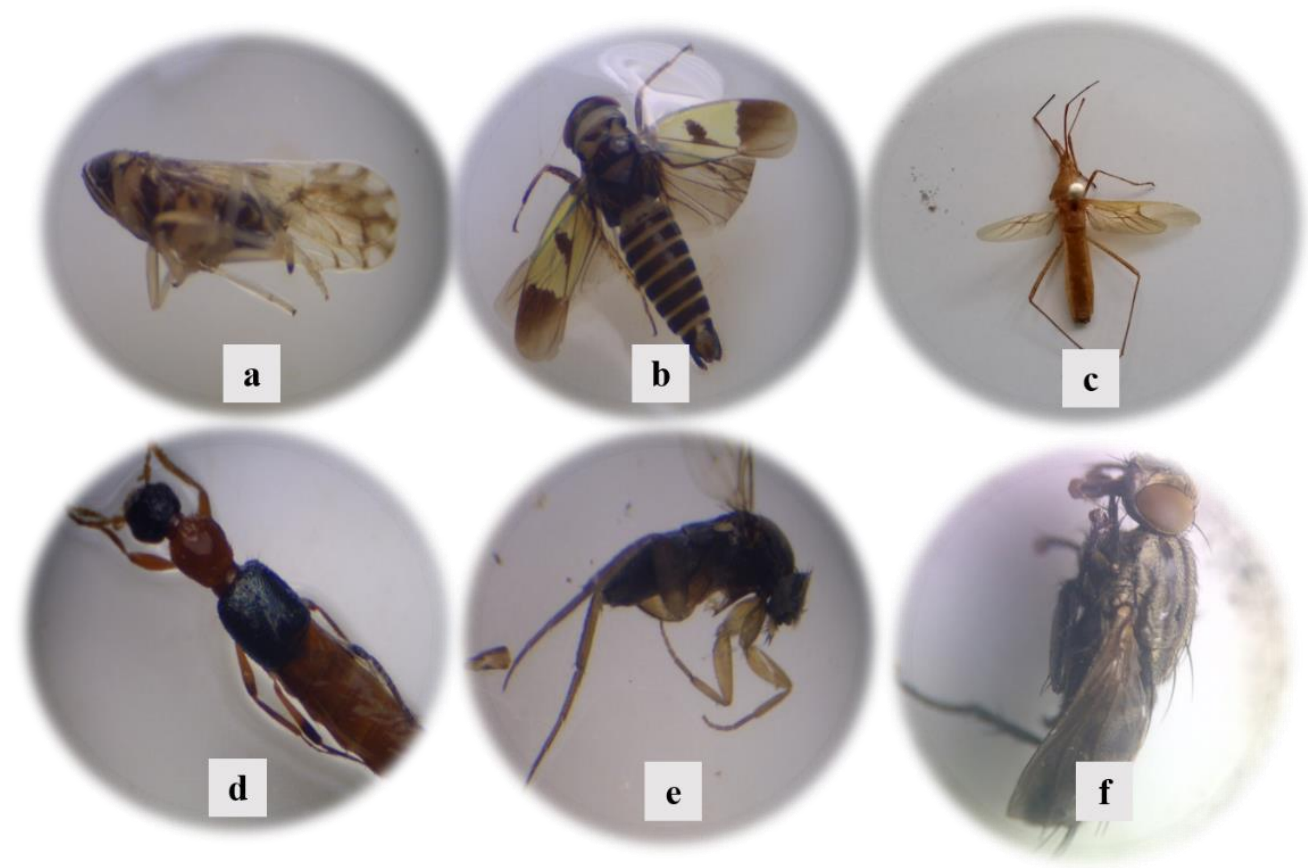

Figure 6 The dominant species of herbivorous insect. a) Nilaparvata lugens; b) Nephotettix virescens; c) Leptocorisa oratorius; dominant species of predatory insect; d) Paederus fuscipes; species dominant of parasitoid insect; e) Phoridae sp.1; and dominant species of Saprofag; and f) Sarcophagidae sp.1.

Daly HV, Doyen JT, Ehrlich PR. 1978. Introduction to Insect Biology and Diversity. International Student Edition. Tokyo (JP): Mc. Graw-Hill, Kogakusha.

Downie IS, Wilson WI, Abernethy VJ, McCracken DI, Foster GN, Ribera I, Murphy KJ, Waterhouse A. 1999. The impact of different agricultural land-uses on epigeal spider diversity in Scotland. Journal of Insect Conservation. 3: 273-286. https://doi.org/ 10.1023/A:1009649222102

Goulet H, Huber JT. 1993. Hymenoptera of the World. An Identification Guide to Families. Ottawa (CA): Agriculture Canada.

Harleni, Purnama Hidayat, Hermanu Triwidodo .2015. Prosiding Seminar Nasional Perlindungan Tanaman II. Bogor (ID): 13 Nopember 2014. Hal: 250-255.

Herlinda S, Yusticia SR, Irsan C, Hadi BAR, Lakitan B, Verawaty M. 2019. Abundance of arthropods inhabiting canopy of rice cultivated using different planting methods and varieties. Journal of Biopesticides. 12(1): 7-18.

Hillebrand H, Bennett DM, Cadotte MW. 2008. Consequences of dominance: a review of evenness effects on local and regional ecosystem processes. Ecology 89. https://doi.org/10.1890/07-1053.1

Janzen DH. 1987. Insect diversity of a Costa Rican dry forest: why keep it, and how?. The Ecological Society of America. 30: 343-356. https://doi.org/ 10.1111/j.1095-8312.1987.tb0030 7.x
Karenina T, Herlinda S, Irsan C, Pujiastuti Y. 2019. Abundance and species diversity of predatory arthropods inhabiting rice of refuge habitats and synthetic insecticide application in freshwater swamps in South Sumatra, Indonesia. Biodiversitas Journal of Biological Diversity. 20(8). https://doi.org/10.13057/biodiv/d200836

Marwoto, Wahyuni E, Neering K. 1991. Pengelolaan pestisida dalam pengendalian hama kedelai secara terpadu. Monograf Balittan Malang. (7): 38.

McAlpine JF. 1987. Manual of Nearctic Diptera Volume 2. Ottawa (CA): Research Branch Agriculture Canada.

Oliveros JC. 2015. Venny an interactive tool for comparing lists with venn diagrams. [internet]. [diunduh 2014 April 14]. Tersedia pada: http://bioinfogp.cnb.csic.es/tools/venny/index.html.

Ovawanda EA, Witjaksono W, Trisyono YA. Insect Biodiversity in Organic and Non-Organic Rice Ecosystem in The District of Bantul. Jurnal Perlindungan Tanaman Indonesia. 20(1): 15-21. https://doi.org/10.22146/jpti.16619

Prabawati G, Herlinda S, Pujiastuti Y. 2019. The abundance of canopy arthropods in South Sumatra (Indonesia) freshwater swamp main and ratooned rice applied with bioinsecticides and synthetic insecticide. Biodiversitas Journal of Biological Diversity. 20(10). https://doi.org/10.13057/biodiv/ d201021 
Rizali A. Buchori D, Triwidodo H. 2002. Insect diversity at the forest margin-rice fiels interface: indicator for health ecosystem. Hayati. 9(2): 41-48.

Schuh RT, Slater JA. 1996. True Bugs of the World (Hemiptera:Heteroptera) Classification and Natural History. Cornell University Press: USA.

Settle WH, Ariawan W, Astuti ET, Cahyana W, Hakim AL, Hindayana D, Lestari AS, Pajarningsih. 1996. Managing tropical rice pest through conservation of generalist natural enemies and alternative prey. The Ecological Society of America. 77: 1975-1988. https://doi.org/10.2307/2265694
Speight MR, Hunter MD, Watt AD. 2008. Ecology of Insects: Concepts and Applications. Oxford (UK): Blackwell Science Ltd.

Taichi T, Mohamed M. 2004. Identification Key to the Families in Diptera (Insecta). Universiti Malaysia Sabah: Japan International Cooperation Agency.

Wiyono S, Widodo, Triwidodo H. 2014. Mengelola ledakan hama dan penyakit padi sawah pada agroekosistem yang fragil denganpengendalian hama terpadu biointensif. Risalah Kebijakan Pertanian dan Lingkungan. 1(2): 116-120. https:// doi.org/10.20957/jkebijakan.v1i2.10303

Zacharia JT. 2011. Ecological effects of pesticides. Dar es Salaam (TZ): Dar es Salaam University Press. 